\title{
An Analysis of the Termination of Credit Business in Faulkner's The Hamlet
}

\author{
Xiuguo Huang \\ School of Interpretation \& Translation, Shandong University at Weihai \\ 180 West Wenhua Road, Weihai 264209, Shandong Province, China \\ E-mail: Xiuguohuang@126.com
}

Doi:10.7575/aiac.alls.v.6n.2p.194

Received: 10/12/2014

URL: http://dx.doi.org/10.7575/aiac.alls.v.6n.2p. 194

Accepted: 13/02/2015

\begin{abstract}
Flem's economic reformation especially his replacement of credit business by cash business in Varner's Store in The Hamlet marked the social transition from a more traditional, closer and bonded community to a rather detached, rational and mechanical commercial society. The description in The Hamlet to a certain extent revealed Faulkner's revulsion at the inhumanity embodied in Flem's success.
\end{abstract}

Keywords: The Hamlet, Credit Business, Social Transition

\section{Introduction}

Earlier studies on The Hamlet concentrated on its structure and Faulkner's conservatism. For example, Malcolm Cowley compared series of episodes in The Hamlet to the beads on a string. Robert Penn Warren paid special attention to its "intricate patterning of contrasts" that established the structure of the novel (Warren 356). T. Y Greet analyzed the function of myth in The Hamlet. The social themes studies were usually devoted to the Faulkner's conservative and nostalgic attitude towards a disintegrating South.

The previous study on Flem Snopes is mainly of ethical criticism. For example James Watson concludes that "through Gavin's unique development, the nature of Snopesism and the impact of Snopes amorality on the moral world are revealed."(Watson 84) And also, there are scholars like Paul Levine who says, "Society does not corrupt Flem Snopes; instead he corrupts society."(Levine 196) In response to these denouncements of Flem's moral degeneration, this paper stresses that Flem's distinctive conduct in fact features the transition of American South from an agrarian community to a commercial society. Flem's replacement of credit business with cash is a typical example of modern enterprise in commercial society.

\section{Discussion}

Together with his family, Flem came to Frenchman's bend to be a share cropper if the local landlord Jody Varner hadn't calculated to rob them of their pathetic fruits of labor. By sharp intuition, Flem thwarted Varners' attempt of blackmailing. He exploited Jody Varner's apprehension of the hearsay of his father, Ab Snopes', arson and got the position of a clerk in the Varner Store. Right after he took the job, Flem refused credit, which has been practiced all the time. This small incident marked a drastic conversion of trade, for "agricultural people typically did business by making purchases on credit and paying at the end of the crop year" (Ownby 9). The change also indicated that the mutual trust in the community and the agrarian notion of paternalism was disdained. Flem's innovation lay in his notion to make profits out of sell rather than simply using the store to support the Varner's hold over the land. Flem's practice coincided with the rationalization of modern economy devoid of emotional ties.

With Flem's reformation in the store and in cotton trade, despite many outward trappings of continuity of community, the hamlet already entered a new phase - the society phase, a term by Ferdinand Tönnies, which consisted of individuals essentially detached and separate.

The Frenchman's Bend citizens all preferred the errors made by Jody to Flem's accuracy.

This signifies the substitution of inhuman machine-like accuracy (with inhuman purposes) for human fallibility. The villagers prefer the errors of Jody, because they recognize the human bond between him and themselves. (Gold 27)

The atmosphere surrounding the landlords and the tenants, the debtors and the obligors, was cordial, amicable and full of human flexibilities. Neither side showed haughtiness or humbleness in their daily association because of their different identities as creditors and debtors. For example, When Will Varner sat among the village men and took part in their confabulation. Hardly any difference in their social standing could be identified. The Varners didn't make light of 
these poor whites because they sponged on his land; these sharecroppers didn't grovel in front of their landlords because they themselves were penniless.

Rich humanity is also manifested in the mutual trust and tolerance in interpersonal relationship that runs parallel in Faulkner's delineation. Customers in Varner's store had practiced self-service for years, which also demonstrated that the dispensable vacancy of clerk was simply fabricated for Flem. Before the arrival of Flem, customers had traded there for years, mostly serving themselves and putting "the correct change into the cigar box inside the cheese café" (Faulkner, 1940: 57). While not serving-themselves, they expected Jody Varner to make mistakes now and then, which enabled some of them to get away with some paltry stuff like a spool of thread or a tin of snuff occasionally. But they were clearly aware of the fact that he would get it back sooner or later. When this little trick was revealed usually with a bluff, both sides would make a joke of it in hearty amiability.

Previous to the arrival of Flem, both the seller and the customer in Varner's store had abundant trust in each other's rectitude. At the same time they maintained their acute awareness of petty shrewdness. The store owner had no worry that he was harassed by the possibility that some of the customers would get away with something else while serving themselves, because ultimately he would correct them. These alleged pilferers would not perspire from embarrassment when they were caught. This kind of familiarity can only stem from the intimacy of those people who know each other very well.

The most apparent distinction between Jody's and Flem's business pattern lies in the latter's reticence and mechanic accuracy in transaction, which shocks and also annoys the hamlet customers. Towards Flem who is alien and foreign to this established community, they hold an instinctive antipathy. Their emotion exemplifies the social exclusion mechanism of a closed community. Social exclusion is the indispensable side effect of social solidarity and cohesion, which means the "individual social marginalization and alienation" that "restricts or denies people participation within society", whose remedy lies in "active membership of individuals in all kinds of voluntary social networks" (Hardcastle 109, 290). Through civic and social engagement, the excluded can develop reciprocity and cohesion with other community members. What is peculiar about Flem is that he is indifferent to the animosity. And he deliberately refuses to change the status quo by insulating himself against any social interaction. He reduced his communication with others, whether it was verbal and visual communication, or body contact, to a minimum. He "answered yes and no to direct questions and who apparently never looked directly or long enough at any face to remember the name which went with it" (Faulkner, 1940: 57).

To the residents, the most noticeable feature in Flem, even on his first day at work in the store was that he was exceptionally taciturn. In contrast to the amicability and Rabelaisian character of the Varner father and son, he spoke little. He never participated in the chat with the other men who gathered and roamed in front of the store. In trading, he would only say yes or no to the customers. When some sharecroppers challenged his figure of the debt, rather than talk back, he would just write their mistake out.

One or two challenging his figures ... the clerk not even listening, just waiting ... until they would finish, cease; then without speaking a word, taking pencil and paper and proving to them that they were wrong. (Faulkner, 1940: 90)

Flem seemed very larruping among the talking foes in Frenchman's Bend that was endowed with the glorious tradition of speech just as any Southern places. Flem even refused the daily greetings from the men that always chatted in front of the Varner store. It was probably because "he has no time for male small talk" (Ownby 119) or he just had no time for anything that couldn't bring him profit.

Compared with Flem's dumbness to the villagers, what's more disturbing was that his machinelike and almost inhuman accuracy that never met any challenges. The residents would prefer Jody's petty mistakes to Flem's absolute accuracy, not because they could make use of these mistakes unfairly, though it happened. Jody's mistakes were usually in his favor. It was because they felt the warmth of human interaction that was reflected in the flaws of human beings. The statement may sound ostensibly discrepant with our traditional understanding. It only makes sense in relation to the inhumanity of the machine-like accuracy. In the description of Flem's mechanical accuracy, Faulkner's humanity concern runs deep. He believes that the quintessential symbol of the devilish demolition power is contained in extreme rationality. As Joseph Gold stated,

The mistakes that Jody has always made in the store disappear when Flem takes over. ... (But) the villagers prefer the errors of Jody, because they recognize the human bond between him and themselves. In Flem they are dealing with an uncontrollable and incomprehensible force. (Gold27)

In a comprehensive survey of the trilogy, one may conclude that Flem is not a law-breaking villain. He is exactly the opposite - an implicit law-abider. It was his extreme rationality and belief in jungle justice that devastated the chance of happiness of his and those around him. His "preeminence" consisted in his superb maneuver of the established norms for his own mileage, while his victims had to suffer mute misery.

Flem's invincibility to a large extent also lies in his obduracy and inexorability which unfortunately coincides with its unprecedented preeminence in modern society. Although his precision in calculation indicates certain fairness, its absence of warmth, which is inalienable to all human beings, ostracizes people. Human fallacy is inherent in humanity 
and therefore it is alluring for human beings. Karl Jaspers once wrote that man could not be deduced. It is in fact, only through a loss of humanity that human behavior becomes in any way deducible, calculable, or machinelike. Flem Snopes saw his human obligations only in terms of inflexible codes and acknowledged no emotional or moral claims upon him. So, Flem might have a morality, but it was a purely mechanical one and the extent of their mechanization was s measure of their inhumanity.

When Flem Snopes never makes a mistake, his impersonal, unfailing accuracy implies that he is not quite human", for he used money contract as a way to extricate him from any personal entanglement. (Broughton 88)

In the aversion of Flem's mechanic accuracy contained Faulkner's central and paramount concern - the impingement of modern civilization particularly in the form of commercialism and mechanized rationality on traditional human values. Faulkner grieved over the potential disintegration of humanity and the precious human truths. Monstrous ogres like Flem typified the horrible inhumanity in mechanic civilization where human factors were abandoned. What Faulkner preferred was characters like the old judge in "Smoke", who believed "that justice was fifty percent legal knowledge and fifty percent unchaste and confidence in himself and in God" (Faulkner, 1949: 11). In this old Judge, in his confidence in himself and god, Faulkner's nostalgia for the esteem of human sentiment could be clearly discerned.

Of course, this personal inclination shouldn't be carried so far as to reach the conclusion that Faulkner was against social development. Rather, Faulkner opposed the waste of humanity during the process of the social transformation in the name of progress. The banishment of humanity rendered Flem more unscrupulous and reckless, who "became symbols of commerce and machinery destroying the standards of the past" (Cowley Viii). Faulkner contradicted that the petty egoist Jody and his fallacy were not necessarily inferior to Flem's mechanical accuracy. Flem's mechanical morality superseded Varner's seemingly primitive and backward business model. But it was devoid of the human warmth that companied the Jody's model, such as the small talk, the comical intercourse, or even the overt self-interest. On the other hand, Faulkner had no desire to idealize Jody's managing model but revealed that he also mercilessly took advantage of its customers. However in Flem's usurpation, a more unmoved, calculative and astute force was introduced while Jody and everything together with him conceded and succumbed.

Flem's dismiss of human bonds is most clearly evidenced by his innovative practice of cash transaction. The termination of the dominant credit business marked a significant diversion from Jody Varner's business mode that insisted no cash in his contract with Ab Snopes. And its reformation tendency had been revealed in the description of the white shirt that Flem wore to the store, in which Faulkner deliberately pointed out that

It was as though its wearer, entering though he had into a new life and milieu already channeled to compulsions and customs fixed long before his advent, had nevertheless established in it even on that first day his own particular soiling groove. (Faulkner, 1940: 51)

Flem immediately entered himself into the fixed customs and left his individual impact on it. He watched, listened, and imitated the behavior of the successful Varners in Frenchman's Bend to the minute detail of a neck bow tie. Yet just as his particular soiling groove on the new white shirt, from the beginning Flem left his leaven on the social circumstances around.

After he took over Varner's store, Flem varied in trading with the citizens of the neighborhood of Frenchman's Bend, among which Flem's most significant innovation was the termination of credit, which the Varners had practiced for such a long time that the tenants had taken it for granted. It had become an economic formula of the sharecropping economy, which didn't own the necessary cash for daily supplies. This particular business mode also reconfirmed the fact that store though it acted as the social center of the Frenchman's Bend and a yoke through which the Varners controlled their sharecroppers, it was still affiliated to the farming economy. The sharecroppers knew and expected that "he (Jody) would give them credit for food and plow-gear when they needed it" (Faulkner, 1940: 57), which superficially appeared to be out of generosity and openhandedness but interest would finally be charged noticeably or inconspicuously. The traditional way of Varners' chase for profit, not charitable at all, was guised in communal kindness, trust and intimacy. Nevertheless, the new clerk aimed to make the store independent from the sharecropping farming system and interrelationship bondage and turned it into a pure commerce. He didn't want to credit anyone with anything. He finally outraged Will Varner by his refusal of further credit to a man who had been into and out of the store's debt for the last fifteen. He roared into the store determined to show Flem who was the real owner of the Varner store. In a sense, the changes that Flem carried out at Varner's store were also changes that were taking place throughout the rural South in the early 20th century as cash replaced credit as the means of payment.

Credit is of enormous significance in sharecropping system, as a personal arrangement and a special affiliation that tightens the connection between land owners and sharecroppers based on the common interest. More like servants, instead of being independent farmers pictured by Thomas Jefferson's ideal, "sharecroppers worked under the direct control of their landlords and possessed no property rights in the goods they produced" (Edwards 76). And credit functions as part of the control that land owners exercises over local farmers, by which they can supervise the sharecroppers' farming work as to what to plant, when to plough and reap. Some of the land owners may even interfere in the farmer's familial consumption. Therefore the hamlet life in Frenchman's Bend has evolved out of the organic community of Tönnies' definition that is "the self-sufficient household ... living in a communitarian way", and 
becomes more like "the market-oriented civil society” (Tönnies 48). The sharecropper's life can no longer be selfsustained, due to the plantation of one-crop aimed for the largest commercial interest. They have to purchase the necessary daily supplies on credit. Mink was such a typical example, who attempted to take advantage of the pasture of his wealthy neighbor because he couldn't feed his farming cow his only production material during the winter. Therefore, long before the arrival of Snopes, Frenchman's Bend had been undergoing the significant social transformation into modern agriculture, but it was only after Flem's arrival that an extreme commercialism was unfolded. This had so far been ignored by most critics. Critics like Richard Godden advocated an understatement of Flem's move rather than unscramble the episode thoroughly.

Whether or not one reads his initial refusal of credit as radical residue or financial innovation, it is conspicuously silly in terms of its outcome. Moreover, the requirement that your boss pay publicly and to the cent for a small item from his own stock may presage a scrupulous adherence to the viewpoint of exchange, but it might equally indicate a residual and ingrained resentment of the carelessness of the wealthy. (Godden 20)

Contradictory to Godden's interpretation, this paper is dedicated to the viewpoint that to play down Flem's refusal of credit to Varner's sharecroppers as ignorance might well lead the readers astray from a good grasp of the mighty theme in Faulkner's works. Without a comprehensive knowledge of the significance of credit in Southern rural society, one may easily overlook its vital function.

In American Southern states the system of industrial peonage also known as the lien law was widely implemented. For example, when a farmer prepared in February for planting he would go to the proprietor of an establishment, which was in most cases was a department store that dealt in every article that he would probably need in his simple life. He would ask the merchant to sell him things on credit until the crop was harvested. He promised the proprietor that he would plant certain amount of cotton or other crop and signed a mortgage upon this unplanted crop. It stated that he could buy necessities he needed on credit from this particular store. Among the two scales of prices, cash and credit, the latter was usually much higher than the former. The excess was the interest that the lien farmer must pay.

Credit played a most important role in Southern economy and "almost everything consumed by the helpless sharecroppers was purchased at inflated credit prices through the merchants' stores" (Mink \& O'Connor 661). The predominance of credit in Southern economic life was stemmed from several factors peculiar to the South, among which there was the prevalent backwardness in the South. And also the Southern farmers were under astringent exploitation. First, the American South was traditionally an underdeveloped zone. It was only after the WWII with the burgeoning sun-belt industry that the South was extricated from the stereotype of poverty and backwardness. In South traditionally cash was in short supply. Furthermore, the defeat in the Civil War exacerbated the scarcity of cash circulated among the residents. The Civil War not only devastated the local military forces but also its economy, particularly the banking system in the South. As it was vividly described in The Hamlet, the poverty-stricken farmers in the countryside possessed little cash for purchase. The request for credit was overwhelming. Credit contributed to the local development. "By providing store credit, merchants boosted the local economy by allowing their customers to invest in land, see, or machinery, thus increasing farm productivity". (Rugh 85) It was known to all in agricultural civilizations, commerce was despised while agriculture was esteemed. Therefore, merchants may often stand out as the prosperous amid the deprived, but they were sometimes compared to "parasites living off a dead or chronically ill body, like Will Varners waiting to foreclose and take the farm and home place away" (Cooper \& Terrill 430). Second, since credit was an absolute necessity for most small farmers, the merchant could easily impose additional clauses on the farmers in the trade. This might elucidate Jody's loftiness and Ab's submission in their first encounter. In the whole process of contracting, it was Jody that set all the requirements and conditions, while Ab did nothing but accept it. In the South, merchants usually used two price systems, "one for cash purchases and a considerably higher price for credit purchases. Merchants charged as much as 50 percent interest and even more." (Cooper \& Terrill 430) Therefore, for the merchants, more profits could be secured in the practice of credit.

Besides, there are other covert benefits with the credit business. In an economic system where little really mattered except land and labor, the store traditionally offered credit as part of the control they exercised over local farmers. The merchants always insisted that the farmer conducted all business at his store to ensure that his monopoly extended to every area of the business. In other words, the merchant predicated his willingness to extend credit on this condition, and the farmers who required credit had no alternative but to accede, for few farmers were able to buy regularly on a cash basis. And the debt between the storeowner and the farmers also forged certain common interests over the future crop. All the above mentioned factors empowered the storeowner to interfere the lives of the farmers, including the details like when to plow, what to plant and how to manage a farm. They could also interfere in their domesticity like the purchase of daily life articles and living conditions. Because customers not only exchanged noted credit to each other but also through the store's ledgers, the network of credit tied the store's customers not only to each other but also to the store. By virtue of the store, the store owner's influence extended well beyond the strictly economic life to all aspects of the rural culture. In fact, the store owner according to Thomas Clark was everything to his community, which was evidenced by the description of Varner's store in The Hamlet where "the store was the hub of the local universe ... the market place, banking and credit source, recreational center, public forum, and news exchange" (Ransom \& Sutch 126). 
At the beginning of The Hamlet, readers witnessed the rapid ascendancy of the rural furnishing merchant, the Varners, and the transformation of his economic power into domination of all aspects of the community life, which was dramatized by the fact that within several years Will Varner had come to dominate the territory in which he operated. With the establishment of the over-lordship, merchants like Varner would coerce farmers into trading only with him, whose monopoly in return further consolidated its domain.

The storekeeper's economic dominance of his market also meant that from the farmer's perspective, the acceptance of credit from an outsider might pose serious risks. If he alienated the local merchant by obtaining funds elsewhere he could find himself cut off from even cash purchases in retaliation. (Ransom \& Sutch 127)

As it was described in The Hamlet, it would be a bad luck if anyone of the sharecropping farmers in the neighborhood did his trading elsewhere.

What's more, most southern states also passed crop-lien laws that gave the furnishing merchants preferential claim to the crops before the claims of landlords for rent or workers for wages. Therefore, in order to ensure their profits, most landowners would keep a store by themselves. As a result, the combination of two roles as landowner and merchant became popular. "Landowners sometimes became merchants themselves, and many merchants became landowners, buying cheaply priced plantations from their profits as suppliers". (Mink \& O'Connor 661) The flourishing pattern of the Varners verified this opinion that

to a large extent it was also within this niche of credit and furnishing that a new class of merchantcreditor emerged to become a major force in the southern rural economy and rival to the planter class, which controlled land but was often unable to supply credit. The lines between merchant and planter often became blurred. (Cooper \& Terrill 310)

Varner was primarily a merchant and moneylender who became a major landowner by extending credit to local farmers and foreclosing on their land when they failed to pay their debts.

All these ensured that there would be a stable number of farm hands for the crop season, usually from February to October. On the other hand, though consumption was encouraged in modern consumer society, it was repulsed and suppressed in the agricultural civilization, where consumption, unless for necessities, would be considered as a waste of energy and also corruption of farming work. This kind of repulse was best summarized in Joe Christmas' foster father, also an independent farmer, Mr. McEachern's fierce denouncement and corporal punishment of Joe Christmas after he found out that Joe secretly went out to town and bought a suit of formal dress.

Due to a lack of cash, agricultural people typically did business by making purchases on credit and paying at the end of the crop year. Purchase on credit could stifle their desire and ability to buy new goods, for the farmers' debt always meant the loss of independence and freedom. What's more, witnessing Varners' foreclose on one farm after another, the farmers in the hamlet had good reason to buy as little as possible. To those buyers on credit, the ledger in Varner's store was more like the sword of Damocles that would bring destruction to them at any time because

customers who cannot pay at the end of the year face the possibility of losing their land. Thus the form of storekeeping that the Varners practice hardly encourages farmers to seek excitement in their goods or in the process of shopping. (Ownby 118)

The customers to Varner's store, mostly sharecroppers, were already in debt to the Varners, shopped mostly for indispensable subsistence. They had more incentives to limit their purchases than enjoy them.

The fact was that the cash morality was comparatively more impartial. In reality so long as he was prepared to pay cash, the farmer had a sufficient number of options to evade exploitation by any would-be monopolist. Yet Flem's more impartial and less exploitative innovation at the store from credit industry to cash industry met vehement boycott both from the store owner and from the exploited customers. The rejection from the side of the Varners was understandable because they suffered loss not only in pecuniary benefit but also in their sphere of social influence. However, the resistance from the customers appeared puzzling, for in cash economy they could cast off both the high interest and the trenchant conditions set by the credit economy. And of course, the repudiation might mainly stem from their dire poverty and lack of cash. But it was more than this. So, the reasons behind their repulse of an economic mode favorable to them deserve more attention.

According to Hosam M. Aboul-Ela, the primary focus of The Hamlet is the death of Yoknapatawpha's rural economy. It is

a story set almost exclusively in a small community called Frenchman's Bend, which centers on a general store owned by Will Varner and is run by his son, important because it extends credit to the community, made up of sharecroppers, (it is of historical importance), when such general stores played a central role in small villages. (Aboul-Ela 85) 
The fact that Flem converted the store from credit to cash mirrored the great change in American society. More profound meanings can be inferred from this seemingly trivial incident. For example, Donald N Yates in his account of the family history talked about the store owned by one of his ancestors, the Yates Cash Market, and said the name "cash" was used for a special purpose. "The 'cash' component of the name stamped it as a modern enterprise. People were to receive the best price, no credit”. (Yates 150) This view was not unique, for Susan Sessions Rugh also said

the increasing use of cash instead of credit was a sign of the country store's absorption into the regional trade and its regularized standards of a long-distance exchange ethic. (Rugh 85)

In a rationalistic cash morality, an impartial trading devoid of all the human influence was preferable to the exploitation that the customers endured in a credit system. In his fiction, Faulkner never turned a blind eye to the merit of commercial society and its inevitable advancement. Nevertheless, the anxiety over the humanity crisis in the influential transformation was also never out of his mind. Flem's precise and almost mechanical calculation and also the extreme cash morality with money as the sole criterion were exactly what the majority of the citizens in the Frenchman's Bend repudiated, for Flem's innovation "disdained the trust that has accompanied the Varner's notions of paternalism" (Ownby 119). Literary critics believed that a revolutionary scene occurred when Flem brought a plug of tobacco to Will Varner and stayed around to ask the owner to pay for the goods of his own store in cash. This was a sign that Flem had successfully taken aim at the economic customs. It also signified that "he was trying to revolutionize the general store to make profits by selling rather than simply using the store to support the Varner's hold over the land" (Ownby 119).

\section{Conclusion}

Finally Flem emulated and surpassed the chief man of Frenchman's Bend Will Varner who suffered the reverse not because he was less cunning or more kind but because with Flem came a more inhuman force. This force was not a curse imposed on them by Northern capitalists. Faulkner tended to exaggerate the difference between the North and South, but it was to a large extent an illusion and self-deception. The South was not soiled by some foreign evil force, whose social transformation was gestated and nourished inside the Southern economy. The story of Flem's success was not an external invasion but a surpass of an apprentice over his master. He first as Varner's protégé "learnt the ways of trade, and managed to pass Jody Varner, the lackadaisical son, as the main inheritor of Varner's status and business savvy" (Cooper \& Terrill 294).

\section{References}

Aboul-Ela, H. M. (2007).Other South: Faulkner, Coloniality, and the Mariátegui Tradition. Pittsburgh: University of Pittsburgh Press.

Broughton, P. R. (1974). William Faulkner: the Abstract and the Actual. Baton Rouge: LSU Press.

Cooper, W. J, \& Terrill, T. E.(1991). The American South. New York: McGraw-Hill, Inc.

Ransom, R. L, \& Sutch, R. One Kind of Freedom: the Economic Consequence of Emancipation. Cambridge: Cambridge University Press, 2001.

Cowley, M., ed. (1985). The Portable Faulkner. New York: Penguin Books.

Edwards, L. F. (1997). Gendered Strife \& Confusion: the Political Culture of Reconstruction. Urbana: University of Illinois Press.

Faulkner, W. (1940). The Hamlet. New York: Random House.

.(1949). Knight's Gambit. New York: Random House Inc.

Godden, R. (2003). “Comparative Cows: or, Reading The Hamlet for Its Residues.” ELH 70: 597-623.

Gold, J. (1962).The “'Normality' of Snopesism: Universal Themes in Faulkner's The Hamlet.” Wisconsin Studies in Contemporary Literature 3.1: 25-34.

Hardcastle, D.A.(2011). Community Practice: Theories and Skills for Social Workers. New York: Oxford University Press, Inc..

Levine, P. (1963). “Love and Money in The Snopes Trilogy”. College English. 23: 196-203.

Mink, G. \& O'Connor. A. (2004). Poverty in the United States: an Encyclopedia of History Politics. Santa Barbara: ABC-CLO, Inc.

Ownby, T. (1995). “The Snopes Trilogy and the Emergence of Consumer Culture.” Faulkner \& Ideology. Eds. Donald M. Kartiganer, \& Ann J. Abadie. Jackson: University of Mississippi Press. 95-129

Rugh, S. S. (2004). Our Common Country: Family Farming, Culture and Community in the $19^{\text {th }}$ Century. Bloomington: Indiana University Press.

Tönnies, F. (2001). Community and Civil Society. Trans. Jose Harris and Margaret Hollis, New York: Cambridge University Press.

Warren, R. P.(1947) Selected Essays. New York: Vintage Books.

Watson, J.G.(1970). The Snopes Dilemma: Faulkner's Trilogy. Coral Gables: Univ. of Miami Press.

Yates, D. N. (1995). The Bear Went Over the Mountain. Princeton: The Cherokee Press. 